\title{
A fatal faecaloma stercoral colitis: a rare complication of chronic constipation
}

\author{
Jonathan Hudson, ${ }^{1}$ Abid Malik ${ }^{2}$
}

${ }^{1}$ Department of Care of the Elderly, Watford General Hospital, Watford, UK ${ }^{2}$ Department of Medicine, Addenbrookes Hospital, Cambridge, UK

\section{Correspondence to} Dr Abid Malik, abidmalik@nhs.net

Accepted 23 August 2015
CrossMark

To cite: Hudson J, Malik A BMJ Case Rep Published online: [please include Day Month Year] doi:10.1136/ bcr-2015-211732

\section{DESCRIPTION}

An 80-year-old woman with type 2 diabetes and hypertension was admitted to hospital with lethargy and confusion. A collateral history revealed she suffered from chronic constipation and had not opened her bowels 'for a few days'. On examination, she was in urinary retention. A catheter was inserted and she was started on treatment for a urinary tract infection.

Subsequently, the patient became tachycardic and hypotensive. Abdominal examination revealed generalised tenderness and hard faecal matter per rectum. Blood tests showed raised inflammatory markers with C reactive protein of $298 \mathrm{mg} / \mathrm{L}$ and a white cell count of $18.3 \times 10^{9} / \mathrm{L}$.

CT of the abdomen and pelvis showed marked rectosigmoid faecal impaction, compression of the urinary bladder (figure 1) and inflammatory changes in the wall of the rectum and lower sigmoid, consistent with a diagnosis of stercoral colitis (figures 2 and 3). The patient was treated with enemas and intravenous antibiotics; despite this, she continued to deteriorate and, given the high operative risk, was deemed unsuitable for surgery and subsequently died.

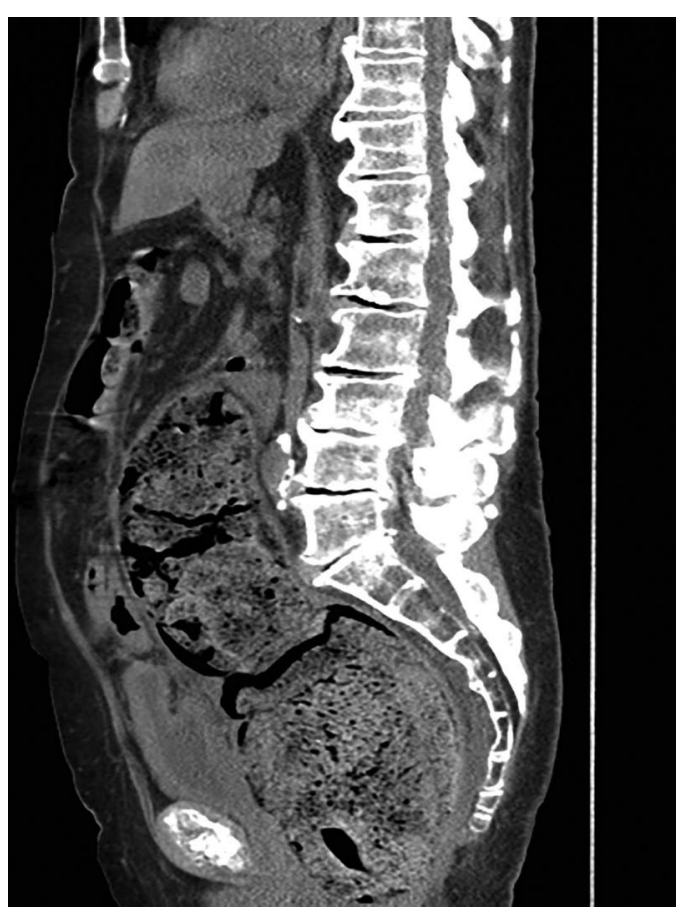

Figure 1 Large faecaloma in the rectosigmoid colon causing compression of the urinary bladder.

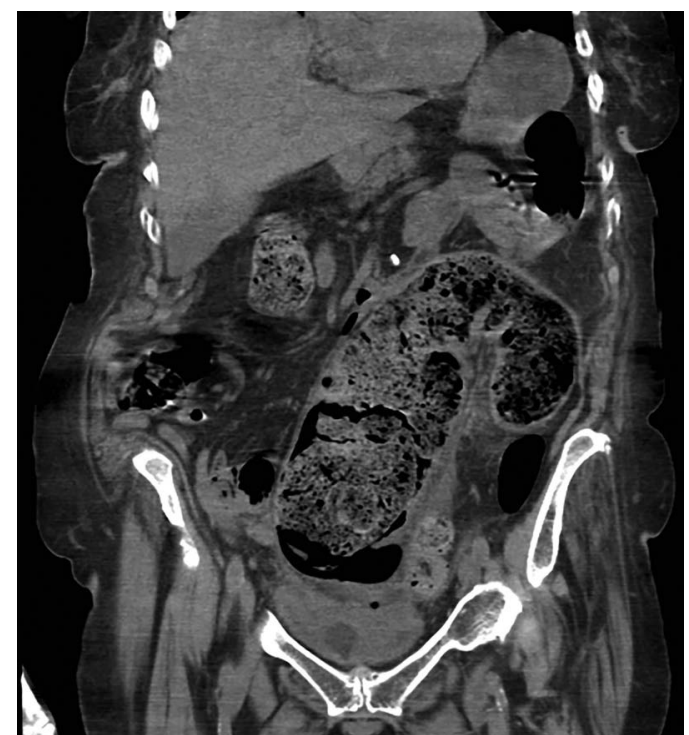

Figure 2 Faecal impaction extending proximally towards the descending colon. Extensive oedematous bowel wall due to compression from the faecaloma.

Stercoral colitis is an uncommon but important complication of chronic constipation. A faecaloma forms, causing distension of the colonic lumen, which decreases the blood supply to the area, ${ }^{1}$ causing a colitis that can progress to ulceration and perforation. A CT scan often shows the classical appearance of a thickened rectum impacted with faeces, dilation of the sigmoid colon and fat stranding of the adjacent bowel. ${ }^{2}$

Management involves prevention of constipation, decompression of the rectum and surgical intervention in those with signs of perforation. ${ }^{3}$

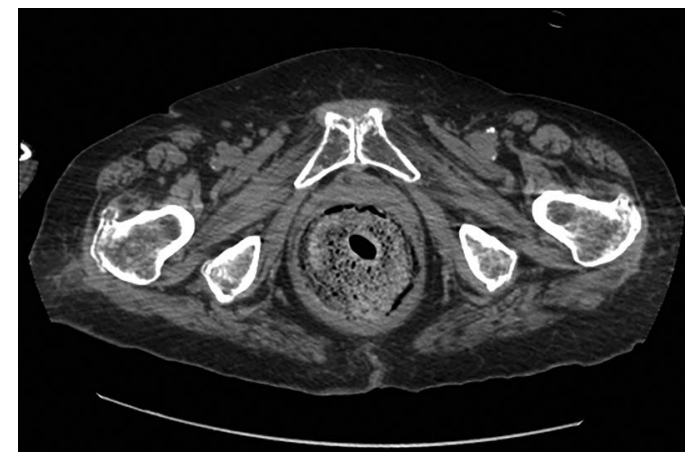

Figure 3 Faecal matter causing distension and thickening of the rectal wall. 


\section{Learning points}

- Stercoral colitis is an uncommon and often fatal complication of chronic constipation.

- It should be considered in all patients who present with abdominal pain and chronic constipation, and especially in the elderly and those with urinary retention.

- CT scan is the modality of choice for diagnosis, and prompt surgical assessment with decompression of the bowel can avoid peritonitis and colonic perforation.
Contributors $\mathrm{JH}$ and $\mathrm{AM}$ were involved in identifying the case, making the diagnosis and implementing appropriate management. JH wrote up the case report, this was supervised and edited by AM.

Competing interests None declared.

\section{Patient consent Obtained.}

Provenance and peer review Not commissioned; externally peer reviewed.

\section{REFERENCES}

1 Chakravartty S, Chang A, Nunoo-Mensah J. A systematic review of stercoral perforation. Colorectal Dis 2013;15:930-5.

2 Heffernan C, Pachter HL, Megibow AJ, et al. Stercoral colitis leading to fatal peritonitis: CT findings. AJR Am J Roentgenol 2005; 184:1189-93.

3 Saksonov M, Bachar GN, Morgenstern S, et al. Stercoral colitis: a lethal disease-computed tomographic findings and clinical characteristic. J Comput Assist Tomogr 2014;38:721-6.

Copyright 2015 BMJ Publishing Group. All rights reserved. For permission to reuse any of this content visit http://group.bmj.com/group/rights-licensing/permissions.

BMJ Case Report Fellows may re-use this article for personal use and teaching without any further permission.

Become a Fellow of BMJ Case Reports today and you can:

- Submit as many cases as you like

- Enjoy fast sympathetic peer review and rapid publication of accepted articles

- Access all the published articles

- Re-use any of the published material for personal use and teaching without further permission

For information on Institutional Fellowships contact consortiasales@bmjgroup.com

Visit casereports.bmj.com for more articles like this and to become a Fellow 